\title{
Pelatihan Desain Grafis Menggunakan Microsoft Publisher bagi Remaja Islam Masjid Darussalam (RISMADA)
}

\author{
Achmad Aditya Ashadul Ushud \\ Universitas Budi Luhur, achmad.aditya@gmail.com
}

\begin{abstract}
Abstrak
Perkembangan teknologi dan informasi yang tidak terbendung lagi, menjadikan desain grafis semakin dibutuhkan. Alasannya karena dengan desain grafis maka informasi dapat disampaikan dalam bentuk yang menarik sehingga informasi dapat ditangkap dengan baik. Kegiatan Pelatihan Desain Grafis Menggunakan Microsoft Publisher ini diikuti oleh peserta yang terdiri dari pelajar SMP dan SMA yang tergabung dalam Remaja Islam Masjid Darussalam (RISMADA) dan remaja di sekitar Komplek Ciledug Indah 2. Tujuan dari kegiatan ini adalah memberikan pengetahuan dan kemampuan untuk mendesain dengan menggunakan Microsoft Publisher. Penggunaan Microsoft Publisher sebagai sarana mendesain dikarenakan aplikasi ini dirasa cukup mudah untuk dipelajari dan digunakan. Metode yang digunakan pada kegiatan ini adalah kombinasi dari tutorial, praktek, dan diskusi atau tanya jawab, dan evaluasi untuk mengetahui tingkat penyerapan terhadap materi pelatihan yang diberikan. Melalui evaluasi di akhir pelatihan, peserta merasakan manfaat dari pelatihan, karena dapat diterapkan dalam tugas-tugas di sekolah yang diberikan. Selain itu, dalam organisasi RISMADA tidak jarang membuat publikasi dengan desain sehingga kemampuan peserta dapat terasah dengan baik.
\end{abstract}

Kata Kunci: desain grafis, Microsoft Publisher

\begin{abstract}
Technological and information advances that are unstoppable, making graphic designs increasingly needed. Because graphic design be able to delivered information in an interesting form so information can be well accepted. This graphic design training using Microsoft Publisher was followed by participants consisting of junior and senior high school students who were members of Remaja Masjid Darussalam (RISMADA) and some youth who lived in Komplek Ciledug Indah 2. The purpose of this activity is to provide knowledge and the ability to design using Microsoft Publisher. The use of Microsoft Publisher as a means of designing because the application is considered quite easy to learn and use. The methods used in this activity are a combination of tutorials, practice, and discussion or questions and answers, and an evaluation to find out the participants level of achievement. Through evaluation at the end of the training, participants feel the benefits of the training, because it can be applied in school assignments. In addition, within the RISMADA organization it is often to make publications with designs so that the ability can be well honed.
\end{abstract}

Keywords: graphic design, Microsoft Publisher 


\section{Pendahuluan}

Desain grafis adalah suatu media informasi yang disampaikan melalui bahasa visual komunikasi dengan memenuhi aturan-aturan estetika bisa dalam bentuk dua dimensi atau tiga dimensi (Dewojati, 2015) . Prinsip-prinsip desain dikelompokkan menjadi: kesatuan, keberagaman, keseimbangan, ritme, keserasian, proporsi, skala, dan penekanan.

Pelatihan ini sengaja diselenggarakan untuk remaja. Di mana usia remaja mulai menghadapi dengan pengalaman-pengalaman dan tugas-tugas baru seiring dengan perkembangan biologisnya (Nasution, 2017). Remaja Islam Masjid Darussalam (RISMADA) Komplek Ciledug Indah 2 adalah remaja yang dalam kesehariannya adalah juga para pelajar SMP dan SMA. Para remaja ini telah terbiasa menggunakan berbagai aplikasi yang terpasang di komputer masing-masing. Namun, karena keterbatasan kemampuan dan ketidaktahuan, maka pemanfaatan aplikasi tersebut masih belum maksimal, khususnya untuk aplikasi yang digunakan untuk desain grafis. Hal ini diketahui dengan melalui survey kepada peserta sebelum mengadakan pelatihan, untuk mengetahui kebutuhan yang dibutuhkan para remaja tersebut. Dengan memberikan pengetahuan dan pelatihan sedini mungkin kepada para remaja yang tergabung dalam RISMADA diharapkan dapat membekali para remaja tersebut agar dapat bersaing di dunia industri di kemudian hari.

Pelatihan desain grafis ini menggunakan perangkat lunak Microsoft Publisher karena sangat mudah dalam pengoperasiannya. Microsoft Publisher dikenal sebagai aplikasi yang secara otomatis mempermudah pekerjaan yang berhubungan dengan desain grafis, karena banyak disediakan template siap pakai (Rista \& Hasanah, 2016). Kelebihan dari Microsoft Publisher pada kemudahan dalam menempatkan teks dan gambar, serta banyaknya ketersediaan template yang siap digunakan. (Priyatno, 2016). Microsoft Publisher terdapat dalam paket perangkat lunak Microsoft Office, yang kadang disebut Office Suite. Penyebutan office (kantor) karena pembuatnya bertujuan perangkat lunak ini dapat menyelesaikan pekerjaan-pekerjaan yang biasanya terdapat di kantor (Weverka, 2016).

Para remaja yang tergabung dalam RISMADA yang tidak memiliki keahlian dalam desain dapat memanfaatkan Microsoft Publisher untuk membuat kartu ucapan, kartu nama, brosur, spanduk, ataupun sertifikat.

\section{Metode}

Metode pembelajaran merupakan pola perencanaan sebagai pedoman untuk melakukan pembelajaran baik di kelas maupun pembelajaran tutorial (Trianto, 2010). Metode yang digunakan pada kegiatan ini adalah kombinasi dari tutorial, praktek, dan diskusi atau tanya jawab, dan evaluasi untuk mengetahui tingkat penyerapan terhadap materi pelatihan yang diberikan. Tahap-tahap yang dilakukan untuk merealisasikan kegiatan ini adalah:

1. Tahapan Pendahuluan

Mempersiapkan kebutuhan peserta beserta dengan pemberian bahan materi yang akan disampaikan. 
2. Tahapan Pelaksanaan

Memberikan pemaparan materi dan praktek yaitu:

a. Pemaparan tentang desain grafis.

Materi berisi pengenalan desain grafis, apa saja yang dibutuhkan untuk dapat mendesain, dan jenis-jenis desain grafis.

b. Pengenalan media publikasi.

Sebelum memaparkan aplikasi yang akan digunakan dalam mendesain, dipaparkan terlebih dahulu mengenai media publikasi yang akan didesain, termasuk jenis-jenis media publikasi. Sehingga peserta mengenal dan paham kebutuhan yang dihadapi nanti.

c. Pemaparan kelebihan Microsoft Publisher.

Pemaparan mengenai kegunaan dari Microsoft Publisher dan perbedaannya dengan aplikasi lain dari Microsoft semisal Microsoft Word, Excel, Powerpoint dan Access yang telah lebih dulu populer.

d. Praktek mendesain menggunakan Microsoft Publisher.

Langkah demi langkah dalam memulai menggunakan Microsoft Publisher untuk mendesain.

3. Tahapan Evaluasi

Evaluasi yang diberikan kepada peserta adalah melihat hasil akhir praktek yang telah dilakukan oleh peserta lalu memberikan masukan.

\section{Hasil dan Pembahasan}

Belajar bertujuan mengubah perilaku sebagai hasil dari ilmu dan pengalaman yang di dapat dari interaksi seseorang dengan lingkungannya (Pane \& Darwis Dasopang, 2017). Dari kegiatan yang dilakukan terhadap para remaja yang tergabung dalam Remaja Islam Masjid Darussalam (RISMADA) Komplek Ciledug Indah 2 diketahui bahwa banyak dari peserta belum mempunyai pengetahuan dan kemampuan dalam mendesain. Kegiatan pelatihan desain grafis ini mendapat sambutan yang sangat baik dari peserta.

Pelatihan ini dilakukan pada hari Minggu 13 Oktober 2019, di Gedung Perpustakaan RW 08 Komplek Ciledug Indah 2, Karangtengah Kota Tangerang, dengan jumlah peserta sebanyak 12 orang. Para peserta pada umumnya belum memiliki kesadaran bahwa desain grafis mengambil peran penting dalam kehidupan sehari-hari. Materi yang diberikan dalam kegiatan ini memberikan wawasan dan pengetahuan yang baru bagi para peserta. Berdasarkan pengakuan peserta kegiatan, kegiatan ini dirasa sangat penting. 


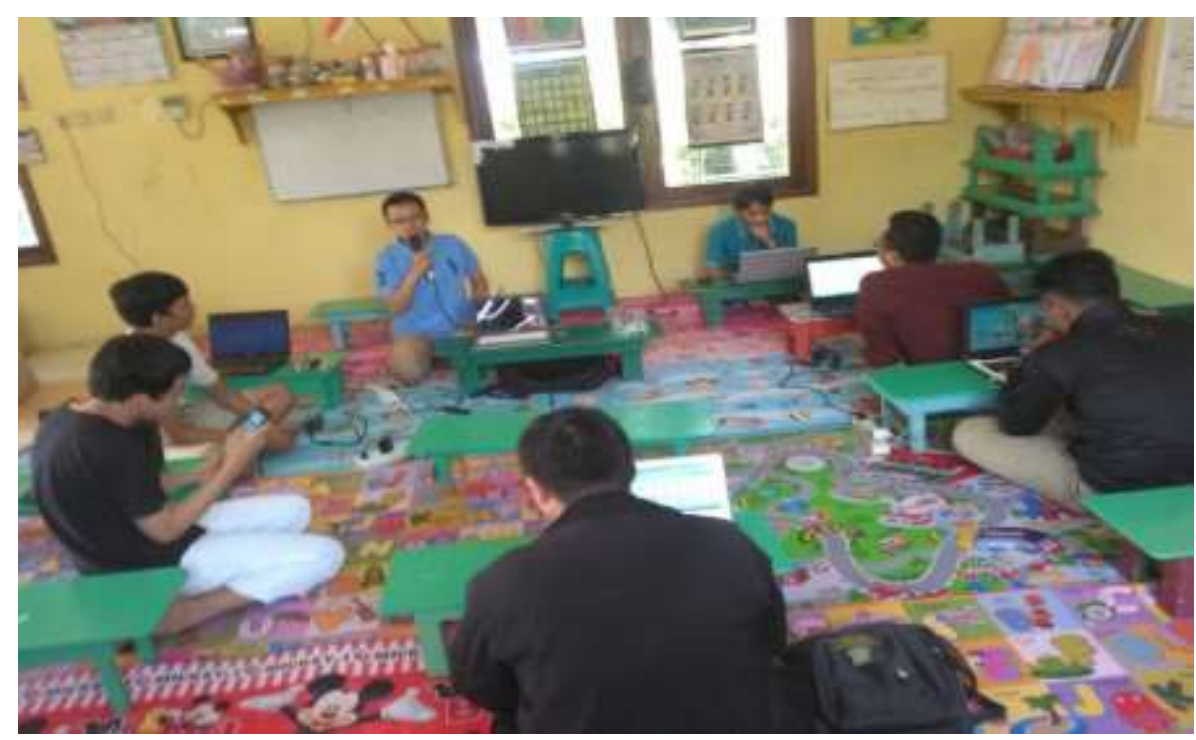

Gambar.1 Pembukaan oleh Ketua RISMADA

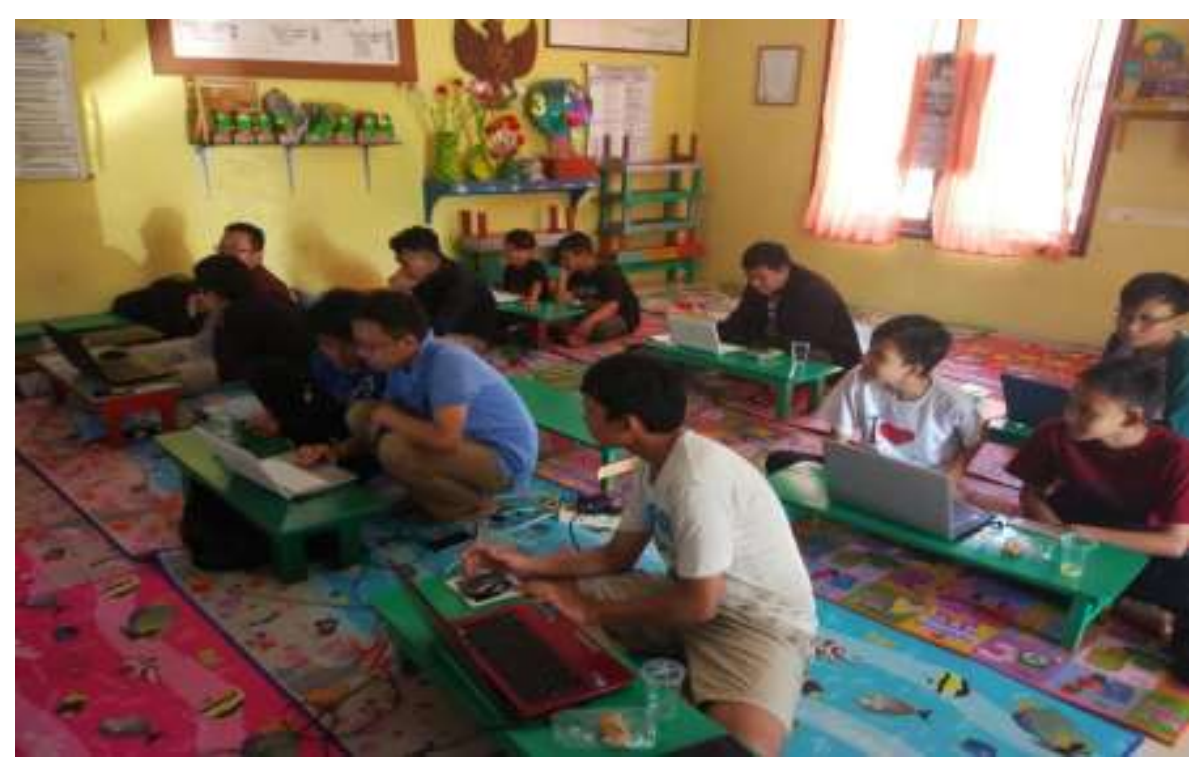

Gambar.2 Peserta sedang mendengarkan arahan

Pemahaman peserta terlihat pada saat diskusi dan tanya jawab peserta dilakukan. Ternyata para peserta mampu menyerap dan memahami materi yang disampaikan, terutama diskusi tentang bagaimana mendesain dengan mudah dan cepat menggunakan Microsoft Publisher.

Dari hasil pertanyaan yang dilakukan dalam diskusi terhadap peserta setelah diberikan materi, maka dapat disimpulkan bahwa peserta mulai dapat mengetahui dan memahami dengan baik bagaimana mendesain dengan menggunakan Microsoft Publisher. 


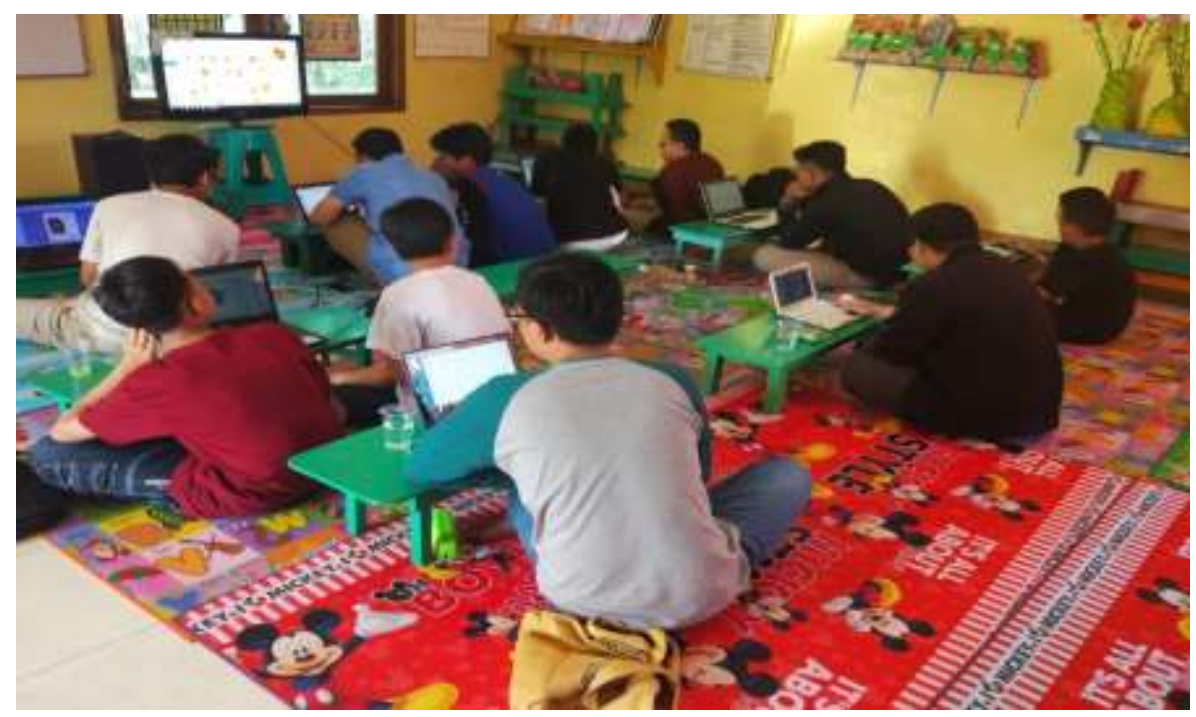

Gambar.3 Peserta sedang praktek membuat desain

\section{Simpulan dan Rekomendasi}

Berdasarkan pemaparan hasil pelaksanaan kegiatan ini maka dapat disimpulkan bahwa kegiatan berupa pelatihan desan grafis menggunakan Microsoft Publisher dapat berjalan dengan baik. Kegiatan ini sangat bermanfaat memberikan pengetahuan dan pemahaman yang lebih mendalam tentang pemanfaatan Microsoft Publisher yang dapat digunakan untuk keperluan tertentu, semisal mengerjakan tugas sekolah maupun di luar itu. Kegiatan ini sekaligus menjadi dorongan bagi para pelajar yang tergabung dalam Remaja Islam Masjid Darussalam (RISMADA) dan remaja di sekitar Komplek Ciledug Indah 2 untuk mengaplikasikan ilmu yang didapat dari pelatihan sekaligus mengajarkan kepada orang yang dikenal. Dengan demikian kegiatan ini secara tidak langsung menjadi bagian untuk turut menambahkan pengetahuan dan kemampuan sebagai bekal dalam mengerjakan tugas sekolah maupun pekerjaan nanti.

\section{Daftar Pustaka}

Dewojati, R. K. W. (2015). Desain Grafis Sebagai Media Ungkap Periklanan. Imaji, 7(2). https://doi.org/10.21831/imaji.v7i2.6633

Nasution, M. K. (2017). Penggunaan metode pembelajaran dalam peningkatan hasil belajar siswa. STUDIA DIDAKTIKA: Jurnal Ilmiah Bidang Pendidikan, 11(1), 9-16.

Pane, A., \& Darwis Dasopang, M. (2017). Belajar Dan Pembelajaran. FITRAH:Jurnal Kajian Ilmu-Ilmu Keislaman, 3(2), 333. https:/ / doi.org/10.24952/fitrah.v3i2.945

Priyatno, D. (2016). Cara Instan Desain Promosi Dengan Microsoft Publisher. Multicom.

Rista, S. C., \& Hasanah, D. F. (2016). Microsoft Publisher Sebagai Office Automation

System dalam Penunjang Pekerjaan Kesekretarisan. 1(1), 66-72.

Trianto. (2010). Mendesain Model Pembelajaran Inovatif-Progresif. Kencana Prenada Media Grup.

Weverka, P. (2016). Office 2016 All-in-One For Dummies. John Wiley \& Sons. Inc. 